Taraxacum stevenii. Удаление осуществляли методом истощения соответствующих растений, то есть многократным срезанием их надземных побегов ножницами, что не вызывало нарушений почвенного покрова и повреждений надземных побегов других сосудистых растений.

Опыты заложены на пробных площадках $1 \mathrm{~m}$ х $0,5 \mathrm{M}$ (повторность четырёхкратная). Оценку результатов проводили на трёх площадках $25 x 25 \mathrm{~cm}$, расположенных в центре каждой площадки 1м х 0,5 м в четырёх вариантах:

1. контроль;

2. удаление Taraxacum stevenii;

3. удаление Sibbaldia procumbens;

4. удаление Sibbaldia procumbens и Taraxacum stevenii.

Как показатель изменения структуры фитоценоза используется численность особей (побегов) сосудистых растений (в - вегетативные, г - генеративные, ю ювенильные) до удаления доминантов. Каждый год подсчитывали число вегетативных, генеративных и ювенильных особей, в случае злаков и осок, учитывали только численность генеративных и вегетативных побегов.

Для статистической обработки результатов эксперимент был использован дисперсионный анализ. По его результатам из 24 видов на удаление доминантов значимую реакцию проявляют: Taraxacum stevenii, Corydalis conorhiza, Carum meifolium, Minuartia aizoides, Gnaphalium supinum, Hyalopoa pontica, Catabrosella variegata, Agrostis vinealis, Anthoxanthum odoratum, Festuca ovina, Phleum alpinum.

На эксперименте при удалении Taraxacum stevenii увеличивают численность побегов следующие виды: Corydalis conorhiza, Hyalopoa pontica, Catabrosella variegata, Festuca ovina, а значимое снижение численности побегов наблюдается у Phleum alpinum.

На эксперименте при удалении Sibbaldia procumbens показали значимое увеличение численности побегов следующие виды: Taraxacum stevenii, Carum meifolium, Gnaphalium supinum, Catabrosella variegata, Anthoxanthum odoratum, Phleum alpinum, а значимое уменьшение численности - Agrostis vinealis.

На эксперименте при совместном удалении обеих доминантов Sibbaldia procumbens+Taraxacum stevenii значительное увеличение наблюдается - у Corudalis conorhiza, Carum meifolium, Minuartia aizoides, Gnaphalium supinum, Catabrosella variegata, Phleum alpinum, а уменьшение только у Agrostis vinealis.

Для видов, у которых происходит значимое увеличение численности при удалении того или иного доминанта, фактор конкуренции оказывается более значимым, чем неблагоприятные условия среды.

\title{
Шаманова Ф.X. \\ Экспериментальный подсев Carum caucasicum на нарушенные участки альпийских ковров
}

Северо-Кавказская государственная гуманитарно-технологическая академия (Россия, КЧР, с. Светлое)

doi:10.18411/spc-22-10-2017-08

idsp: 000001:spc-22-10-2017-08

Carum caucasicum (Bieb.) Boiss. - травянистый поликарпик, полурозеточный, стержневой, вегетативно неподвижный геофит. Энтомофил. В ТГБЗ встречается в альпийском и субнивальном поясах, доходя до 3750м, но особенно характерен для альпийского пояса, где произрастает на пустошах и коврах. Этот вид является субэндемом Кавказа. Поселяется на средних стадиях сукцессии, приводящих к образованию ковра. Имеет везикулярно-арбускулярную микоризу.

Эксперимент проводили на нижних участках альпийских ковров, которые располагались на абсолютной высоте 2800м на горе Малая Хатипара в ТГБЗ. 
Данный эксперимент был заложен в 4-х вариантах:

1) контроль,

2) контроль нарушением (удаление надземной биомассы присутствующих видов сосудистых растений),

3) подсев Carum caucasicum на ненарушенные площадки,

4) подсев Carum caucasicum на площадки с нарушением (удалением надземной биомассы),

Размеры экспериментальных площадок 10 х 10 см (повторность 20-ти кратная). Удаление надземной биомассы производили ножницами, не нарушая мохового покрова и верхнего слоя почвы. На каждую площадку подсевали по 100 семян в течение трех лет. Подсев осуществляли в первой половине сентября семенами, собранными в ближайших популяциях этих видов. Проростки и ювенильные особи подсчитывали ежегодно два раза в течение вегетационного периода.

В вариантах контроль и контроль с удалением надземной биомассы появление проростков данного вида не отмечено, поэтому в дальнейшем данные варианты рассматривать не будем. Таким образом, естественного возобновления исследуемых видов на наших площадках не наблюдается.

Наибольшее число всходов и ювенильных особей к концу первого года эксперимента отмечено в варианте, когда семена подсевали на ненарушенные участки 103 побега C.caucasicum (рис.1). Итоговые показатели в этом варианте для второго года составили 114 побега. На третий год наблюдений число всходов и ювенильных особей отмечено на варианте - подсев на ненарушенные участки - 194 побега C. caucasicum. Четвертый год эксперимента показал на варианте - подсев на ненарушенные участки 187 побега. В результате пятого года эксперимента число всходов и ювенильных особей для C.caucasicum отмечено наибольшее число всходов и ювенильных особей на варианте - подсев на ненарушенные участки - 202 побега. Итоговые данные за шестой год на варианте - подсев на ненарушенные участки - 162 побега. Важно отметить, что именно на шестой год эксперимента при подсеве на ненарушенные участки появляются первые особи, перешедшие во взрослое виргинильное (вегетативное) состояние 14 растений C.caucasicum. В целом приживаемость за эти шесть лет наблюдений на данном варианте составила около 1,5\% для C.caucasicum.

Если в целом рассматривать каждый год эксперимента, то на варианте с предварительным удаление надземной биомассы растений всхожесть семян и приживаемость всходов были существенно ниже, чем на варианте, когда семена подсевали на ненарушенные участки. К концу первого года эксперимента всхожесть составила 4 особей у C.caucasicum (рис.2). К концу второго года эксперимета эти показатели составили 9 особей для C.caucasicum от подсеянных семян за два года эксперимента. Итоговые показатели третьего года эксперимента составили 27 особей C.caucasicum (от 6000 семян) На четвертый год эксперимента отмечено наибольшее число всходов и ювенильных особей в варианте - подсев на нарушенные участки для C.caucasicum - 97 особей. На пятый год всего было 47 особей C.caucasicum. Итоговые показатели в этом варианте для шестого года составили 34 особей для C.caucasicum. За годы наблюдений приживаемость для данного варианта составила $0,4 \%$ для C.caucasicum.

Наибольшее число развившихся ювенильных особей характерно также для варианта подсева на ненарушенные участки 187 особей у C.caucasicum. Интересно отметить, что количество ювенильных особей в этом варианте увеличиваются с каждым годом. Можно предполагать о тенденции повышения приживаемости всходов в данном варианте.

Количество ювенильных особей в варианте подсева на нарушенные участки существенно ниже - 36 особей у С.caucasicum. В этом варианте мы наблюдаем 
незначительное увеличение ювенильных особей к концу пятого года эксперимента, хотя в год засухи все ювенильные особи погибли.

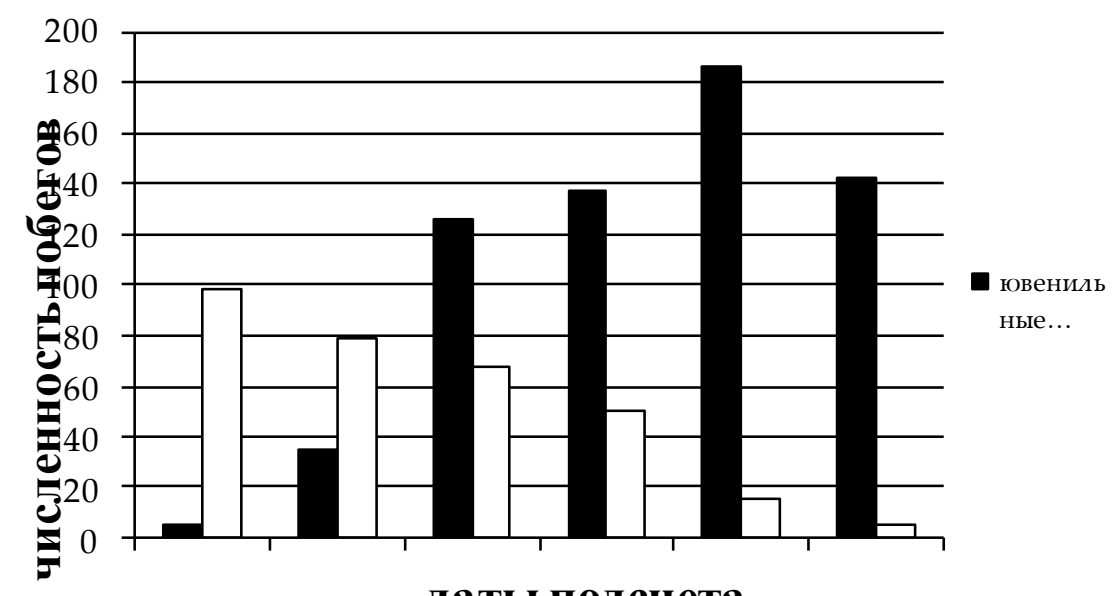

даты подсчета

Рис.1. Диаграмма численности всходов и ювенильных особей Сатит саисаsісит на ненарушенных участках.

90

80
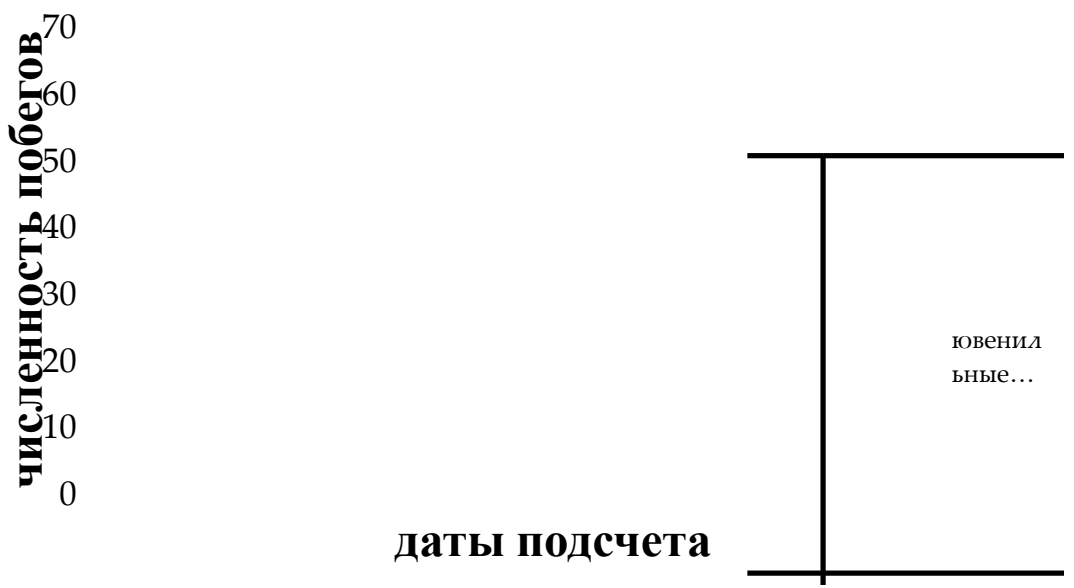

Рис.2. Диаграмма численности всходов и ювенильных особей Сатит саисаsісит на участках с удалением надземной биомассы

Таким образом, всхожесть семян Carum caucasicum при подсеве на альпийские ковры невысокая. За эти шесть лет эксперимента на ненарушенных участках она составила $1,5 \%$ для Carum caucasicum (по отношению к общему числу подсеянных семян). На нарушенных участках этот показатель существенно ниже - 0,4\% Carum caucasicum. При этом отмечается довольно высокая смертность всходов.

За пять лет эксперимента во всех случаях проростки достигали только ювенильного состояния и лишь на шестой год появились вегетативные особи. Это подтверждает большую длительность развития альпийских растений.

В суровых условиях существования ковров фактор конкуренции для проростков оказался менее значимым, чем неблагоприятные абиотические факторы среды. Растения на коврах имеют низкий шпалерный рост и, возможно, на ненарушенных участках снижают действие перепадов температур и иссушения поверхности почвы на всходы, поэтому подсев Carum caucasicum более целесообразно производить на ненарушенные сообщества. 